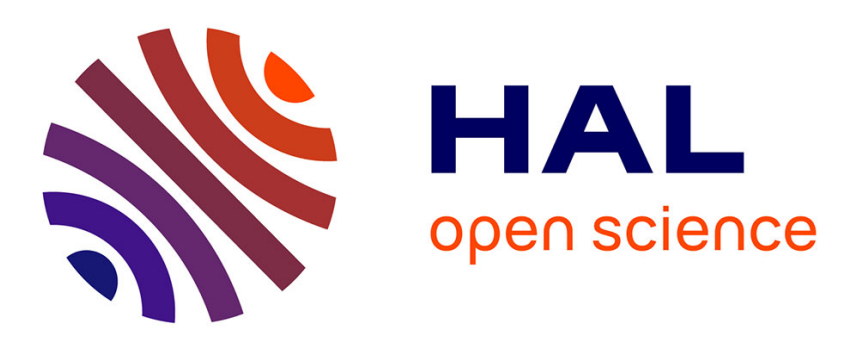

\title{
A new era in hydrofluoric acid solution calorimetry: Reduction of required sample size below ten milligrams.
}

\author{
Guy L. Hovis, Jacques Roux, Pascal Richet
}

\section{To cite this version:}

Guy L. Hovis, Jacques Roux, Pascal Richet. A new era in hydrofluoric acid solution calorimetry: Reduction of required sample size below ten milligrams.. American Mineralogist, 1998, 83, pp.931934. hal-00077571

\section{HAL Id: hal-00077571 \\ https://hal-insu.archives-ouvertes.fr/hal-00077571}

Submitted on 31 May 2006

HAL is a multi-disciplinary open access archive for the deposit and dissemination of scientific research documents, whether they are published or not. The documents may come from teaching and research institutions in France or abroad, or from public or private research centers.
L'archive ouverte pluridisciplinaire HAL, est destinée au dépôt et à la diffusion de documents scientifiques de niveau recherche, publiés ou non, émanant des établissements d'enseignement et de recherche français ou étrangers, des laboratoires publics ou privés. 


\title{
A new era in hydrofluoric acid solution calorimetry: Reduction of required sample size below ten milligrams
}

\author{
Guy L. Hovis, ${ }^{1, *}$ Jacques Roux, ${ }^{2}$ and Pascal Richet ${ }^{3}$ \\ 'Department of Geology and Environmental Geosciences, Lafayette College, Easton, Pennsylvania 18042, U.S.A. \\ ${ }^{2}$ CNRS-CRSCM, 1A, rue de la Ferollerie, 45071 Orleans Cedex 2, France \\ ${ }^{3}$ Institut de Physique du Globe, 4, place Jussieu, 75005 Paris, France
}

\begin{abstract}
Significant advances have been made in hydrofluoric acid solution calorimetry at Lafayette College in the past 15 years. To determine the degree to which these developments enable the reduction of sample size, calorimetric experiments were performed on hexagonal germanium oxide as a function of sample weight. The resulting calorimetric data indicate that the highest degrees of reproducibility $( \pm 0.1 \%)$ are maintained down to sample sizes of $50 \mathrm{mg}$, and that precisions of $\pm 1 \%$, acceptable for many applications, are observed to sample sizes of $10 \mathrm{mg}$. Because silicate systems produce weight-based heats of solution that are about twice that of germanium oxide, the required sample size for these will be even less. The new minimum required sample size of 5 to $25 \mathrm{mg}$ (depending on application) is about two orders of magnitude less than that used 20 or 30 years ago. This makes possible many new kinds of projects for HF solution calorimetric investigation, including those on high-pressure materials.
\end{abstract}

\section{INTRODUCTION}

Hydrofluoric acid (HF) solution calorimetry (see Waldbaum and Robie 1971 or Robie and Hemingway 1972) has long had the reputation of requiring large sample sizes. Indeed, 20 to 30 years ago it was commonplace in such work to use sample sizes of 750 to $1000 \mathrm{mg}$ per dissolution (e.g., Waldbaum and Robie 1971 or Hovis 1974). More than a decade ago, however, the emerging availability of various kinds of electronic apparatus improved calorimetric measurements. More recently, improved digital voltmeters have further increased the precision with which (typically low) calorimetric voltages can be measured. Although smaller sample sizes have been employed for years on the Lafayette College calorimetric system as a result of these enhancements, it is only recently that we have tested our system in terms of how these improvements relate to new limits on sample size.

\section{HF SOLUTION CALORIMETRY AND CALORIMETRIC APPARATUS}

In principle a hydrofluoric acid solution calorimetric experiment is simple. One dissolves a substance in HF (our experiments normally use a $20.1 \mathrm{wt} \%$ solution) and measures the temperature change that ensues. Then, by measuring the heat capacity (given as energy/degree) of the dissolution vessel (calorimeter), one associates the observed temperature change with a corresponding energy change. Knowing the weight of the sample dissolved, one

*E-mail: hovisguy@lafvax.lafayette.edu converts this energy into energy per gram or energy per mole: Voila, the heat (or enthalpy) of solution.

What makes high-precision calorimetry difficult is that the temperature changes $(\Delta T)$ associated with dissolution and with the determination of calorimetric heat capacity (accomplished by heating the calorimeter electrically and measuring the resulting temperature change) are normally very small, so they must be measured with extreme precision. The smaller the sample, the smaller is the $\Delta T$ of dissolution. Moreover, it is impossible to isolate the calorimeter well enough to completely eliminate the exchange of heat with its environment, so one must be able to rigorously correct the observed values of $\Delta T$ for such exchange; this too requires highly precise temperature determinations. Finally, even the best calorimetric measurements are of little value if sample weight is not known with a high degree of accuracy.

To minimize the energy exchanged between the calorimeter and its environment, before the start of an experiment, the calorimeter and its contents are heated to a temperature close to (but just below) that at which dissolution is to occur (in our case, normally $50{ }^{\circ} \mathrm{C}$ ). Moreover, the calorimeter is submerged in a medium (for our system a water bath) whose temperature is held constant near the intended dissolution temperature. (Note that there is a distinction between the bath temperature, $T_{\text {bath }}$, and the convergence temperature of the system, $T_{\text {convergence }}$, the temperature to which the calorimeter would drift at infinite time; the small difference between the two is due to the addition of heat to the calorimeter from stirring.) In addition, the calorimeter is physically isolated from the 


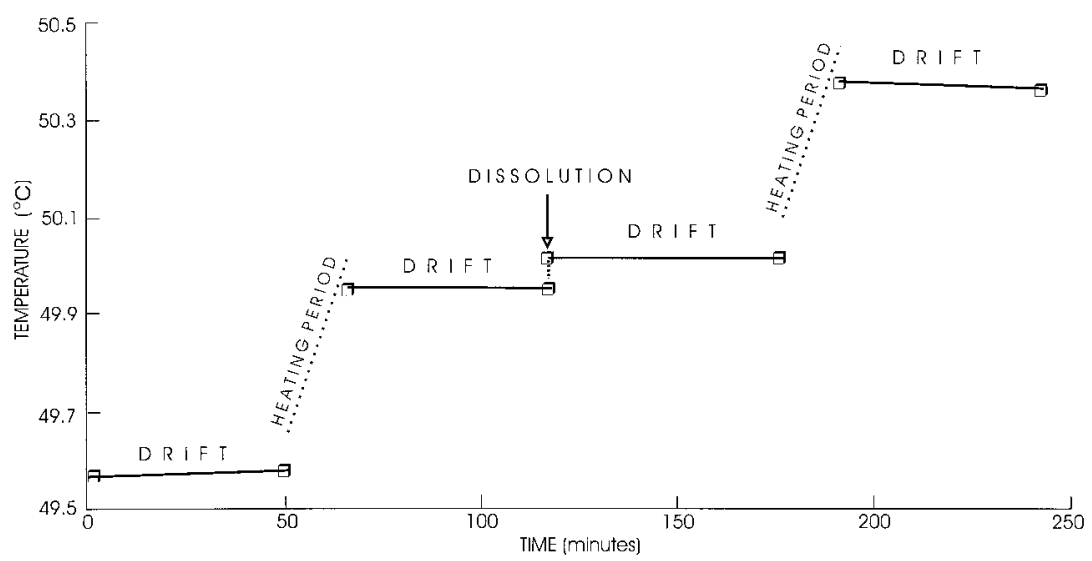

bath inside a stainless steel container (called a "submarine"), and a moderately high vacuum $\left(10^{-5}\right.$ torr $)$ is established between the inner submarine and outer calorimeter walls. Because calorimetric temperatures generally rise during an experiment, the calorimeter gains heat from its environment at the beginning of an experiment ( $T_{\text {calorimeter }}<T_{\text {convergence }}$ ), but loses heat by the conclusion of an experiment $\left(T_{\text {calorimeter }}>T_{\text {convergence }}\right)$.

\section{IMPROVEMENTS IN HF SOLUTION CALORIMETRY}

A temperature-time plot of a typical calorimetric experiment, utilizing current apparatus, is shown in Figure 1. During such an experiment there are four so-called drift periods, one on each side of a heating or dissolution period. Drift periods, normally 50 min long, are periods when calorimetric temperature is monitored as a function of time while no other processes are occurring. They reflect the rate of heat exchange between the calorimeter and its environment, but more importantly they allow correction to the observed values of $\Delta T$ for heat exchange that occurs during heating (calibration) and dissolution periods. Because the calorimeter and bath temperatures are close to one another at all times, heat gained or lost by the calorimeter is generally small. Moreover, the presence of the vacuum results in changes of temperature during drift periods that are for all practical purposes linear (nonlinearity being undetectable) as a function of time; this in turn makes corrections to $\Delta T$ straightforward.

Calorimetric temperatures are measured by determining the resistance of a copper coil that is wound noninductively around the outside of the calorimeter in a continuous layer that completely covers its exterior. Resistance of the wire is determined from measurements of its
Figure 1. The scanned plot of temperature against time for an actual calorimetric experiment employing current equipment and data reduction techniques. Lines are least-squares fits to densely packed data points that collectively are not discernible from the lines themselves. Note that the drift period at the beginning of the experiment has a positive slope, while that at the end is negative, as explained in the text. The jump in temperature at the beginning of a heating period is associated with superheating of the thermometer, just as the precipitous decrease in temperature at the end of a heating period is related to subsequent thermal equilibration after the heater is turned off; these are accounted for in the data reduction. The overall temperature increase during most experiments, including temperature rises during heating periods, is on the order of $1{ }^{\circ} \mathrm{C}$. The $0.062{ }^{\circ} \mathrm{C} \Delta T$ of dissolution in this experiment is about 20 times those of the 10 mg samples in Table 1. voltage and current, the latter measured as voltage across a standard resistor in series with the copper coil. During heat capacity determinations, electricity is introduced through a second layer of copper wire wound non-inductively around the exterior of the vessel; energy is measured by monitoring the voltage and current of the wire (as described above), as well as the time during which electricity is engaged. During the course of an experiment, then, there are four voltage circuits that must be monitored, a voltage and a current circuit each for the thermometer and the heater. Clearly, the quality of calorimetric data depends in large part on the precision and frequency of these voltage measurements.

Twenty or thirty years ago, all calorimetric voltage measurements, both for temperature and energy determination, utilized a potentiometer and null detector. Because potentiometer dials were set manually, it was impossible to switch back and forth between voltage and current circuits quickly. In fact, relative to Figure 2, older calorimetric data did not involve a plot of temperature against time, but rather of voltage (mostly thermometer voltage) against time, with an occasional measurement of current. Voltage data were recorded on a strip chart, and "fits" to voltage-time data were done manually. In general, the monitoring of temperature was not accomplished continuously as with current electronic apparatus, nor were the manual fits of voltage-time data as accurate as current least-squares analyses of voluminous computerstored temperature-time data.

More than a decade ago the data collection components of the Lafayette College calorimetric system were completely automated, as reported in Figure 1 of Hovis and Roux (1993). An electronic scanner (Hewlett Packard 


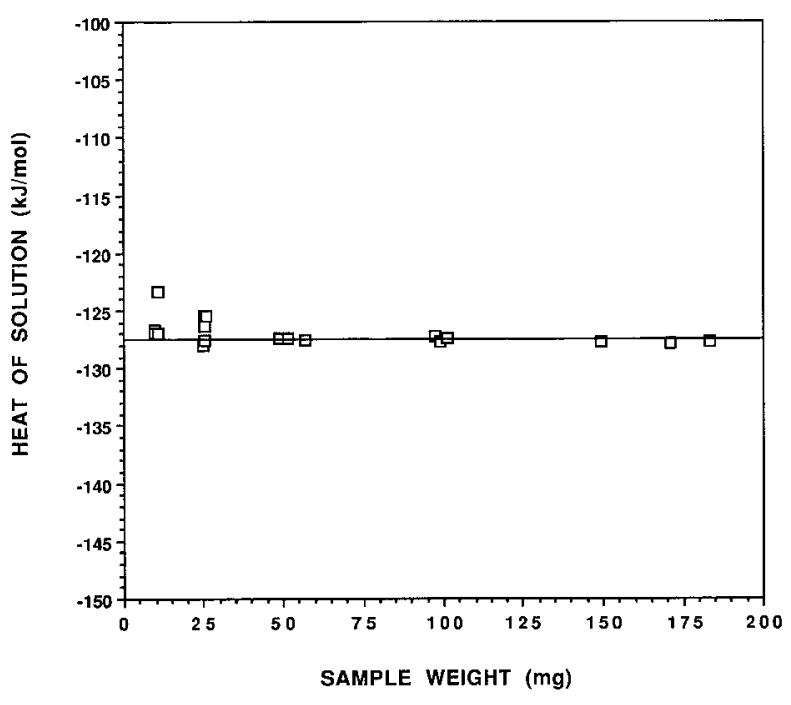

Figure 2. Enthalpies of solution as a function of sample size for germanium oxide experiments of this investigation. The horizontal line represents an average heat of solution of -127.56 $\mathrm{kJ} / \mathrm{mol}$ based on samples having weights greater than $49 \mathrm{mg}$.

Model 3497A) permitted virtually instantaneous switching between current and voltage circuits, as well as between heater and thermometer circuits. A computer-based system made possible the storage of large volumes of data that could be time-averaged. More recently we have replaced our digital voltmeter (HP Model 3456A) with a higher precision model (HP Model 3458A) that adds two significant digits to the precision with which low-level voltages can be determined. Thus, the precision with which values of $\Delta T$ now can be determined is improved even further relative to those of earlier automation. In addition, we have obtained a highly precise electronic balance (Mettler Model AT201) that allows sample weight to be known to a higher degree of accuracy than before.

\section{EXPERIMENTAL PROCEDURES}

To test the degree to which these improvements have affected calorimetric precision and the minimum required sample size, we performed dissolutions on hexagonal germanium oxide [unit-cell parameters, $a=4.9850$ $( \pm 0.0002) \AA$ and $c=5.6476( \pm 0.0002) \AA)]$ as a function of sample size. Germanium dioxide $\left(\mathrm{GeO}_{2}\right)$ is a good substance for such measurements, because it dissolves quickly, minimizing the correction to $\Delta T$ for heat exchange during the dissolution period. However any number of quick-dissolving substances, including feldspathoids, zeolites, and hydroxides, would have been equally viable candidates for this study. The $\mathrm{GeO}_{2}$ was unground, commonly a single chunk or two of material per experiment. Even with such coarse material, dissolutions generally were completed in 3 or $4 \mathrm{~min}$.

As is normal in our work, each dissolution was conducted near $50{ }^{\circ} \mathrm{C}$ in $910.1 \mathrm{~g}$ (about a liter) of $20.1 \mathrm{wt} \%$
HF under isoperibolic conditions, i.e., $T$ of the surroundings remains constant. In some cases, noted in Table 1, two dissolutions were made in the same acid solution. This had no detectable effect on the results, undoubtedly because of the high dilution of dissolved ions in the acid. Five weight classes of $\mathrm{GeO}_{2}$ were studied, including samples of $166( \pm 18), 100,50,25$, and $10 \mathrm{mg}$.

\section{Calorimetric Results and discussion}

Table 1 and Figure 2 record the results of our experiments. All weight classes produced the same average heats of solution within two standard deviations of the data. The collective average heat of solution of hexagonal $\mathrm{GeO}_{2}$ for the 166,100 , and $50 \mathrm{mg}$ weight classes was $-127.56 \pm 0.19 \mathrm{~kJ} / \mathrm{mol}$, shown as the horizontal line in Figure 2.

Even though average heats of solution for the five weight classes are essentially the same, there are differences among them in the reproducibility of results (seen on Fig. 2), thus in standard deviation (last column of Table 1). For the three highest weight classes, \pm 1 full standard deviation in the data constitutes just $\pm 0.08,0.14$, and $0.03 \%$, respectively, of the observed heats of solution. This is the same degree of reproducibility that we have observed with other quick-dissolving substances (e.g., leucite, analcime, and pollucite) since this study was completed. However, the corresponding percentages for the 25 and $10 \mathrm{mg}$ weight classes are \pm 0.9 and $1.3 \%$, respectively. Even though this precision is less than for samples $50 \mathrm{mg}$ and above, these still constitute relatively small uncertainties that are appropriate for many types of projects.

It is instructive to note the heat generated by the dissolution of $\mathrm{GeO}_{2}$ on a weight basis, which is equal to $-1220 \mathrm{~J} / \mathrm{g}$. In magnitude, this is significantly less than the corresponding heats of solution for many silicate minerals. Alkali feldspars (Hovis 1988), plagioclase feldspars (Hovis 1997), muscovite-paragonite micas (Roux and Hovis 1996), nepheline-kalsilite (Hovis and Roux 1993), leucite, sodalite, and analcime (unpublished data) produce weight-based heats of solution that are about twice that of $\mathrm{GeO}_{2}$. The minimum weight requirements for these compounds most likely will be even less than those for $\mathrm{GeO}_{2}$.

\section{Conclusions}

Hydrofluoric acid solution calorimetry has changed significantly in the past 15 years. Improved precision in measurement apparatus and techniques have resulted in the reduction of required sample size by two orders of magnitude relative to that of the early 1980s. Calorimetric temperature changes as small as $0.003{ }^{\circ} \mathrm{C}$ associated with the dissolution of solids are now detectable and highly reproducible. [Hemingway and Robie (1977) show that even smaller values of $\Delta T$ will be detectable for the virtual instantaneous dissolution of liquids.] Although the minimum sample weight required for a project depends on the purpose of the project and the magnitudes of en- 
TABLE 1. Calorimetric data for hexagonal germanium oxide

\begin{tabular}{|c|c|c|c|c|c|c|c|c|}
\hline $\begin{array}{c}\text { Exper. } \\
\text { No. }\end{array}$ & $\begin{array}{c}\text { Sample } \\
\text { weight } \\
\text { (g) }\end{array}$ & $\begin{array}{l}\text { Temperature } \\
\text { change during } \\
\text { dissolution } \\
\left({ }^{\circ} \mathrm{C}\right)\end{array}$ & $\begin{array}{c}\text { Mean } \\
\text { solution } \\
\text { temperature } \\
\left({ }^{\circ} \mathrm{C}\right)\end{array}$ & $\begin{array}{c}\text { Calorimeter } \\
\text { heat } \\
\text { capacity I } \\
\text { (J/deg) }\end{array}$ & $\begin{array}{l}\text { Calorimeter } \\
\text { heat } \\
\text { capacity II } \\
(\mathrm{J} / \mathrm{deg})\end{array}$ & $\begin{array}{l}\text { Heat of } \\
\text { solution I } \\
\left.\text { (from } C_{\mathrm{p}} \mathrm{I}\right) \\
(\mathrm{kJ} / \mathrm{mol})\end{array}$ & $\begin{array}{l}\text { Heat of } \\
\text { solution II } \\
\text { (from } C_{\mathrm{p}} \text { II) } \\
(\mathrm{kJ} / \mathrm{mol})\end{array}$ & $\begin{array}{c}\text { Average } \mathrm{H}_{\text {soln }} \\
\quad(\mathrm{kJ}) \\
\pm 1 \text { Std dev (kJ) } \\
\pm 1 \text { Std dev (\%) }\end{array}$ \\
\hline \multicolumn{9}{|c|}{ 149-184 mg samples } \\
\hline $\begin{array}{l}721 \\
724^{*} \\
733\end{array}$ & $\begin{array}{l}0.17082 \\
0.18355 \\
0.14941\end{array}$ & $\begin{array}{l}0.054015 \\
0.057990 \\
0.047184\end{array}$ & $\begin{array}{l}50.036 \\
50.041 \\
49.995\end{array}$ & $\begin{array}{l}3873.3 \\
3870.3 \\
3875.9\end{array}$ & $\begin{array}{l}3875.0 \\
3871.8 \\
3876.5\end{array}$ & $\begin{array}{l}-127.85 \\
-127.64 \\
-127.77\end{array}$ & $\begin{array}{l}-127.90 \\
-127.68 \\
-127.78\end{array}$ & $\begin{array}{c}-127.77 \\
\pm 0.10 \\
\pm 0.08 \%\end{array}$ \\
\hline \multicolumn{9}{|c|}{100 mg samples } \\
\hline $\begin{array}{l}734 \\
737 \\
742^{*}\end{array}$ & $\begin{array}{l}0.09750 \\
0.10118 \\
0.09918\end{array}$ & $\begin{array}{l}0.030675 \\
0.031881 \\
0.031337\end{array}$ & $\begin{array}{l}50.004 \\
49.997 \\
49.991\end{array}$ & $\begin{array}{l}3876.0 \\
3874.0 \\
3870.5\end{array}$ & $\begin{array}{l}3875.8 \\
3874.2 \\
3871.6\end{array}$ & $\begin{array}{l}-127.29 \\
-127.42 \\
-127.65\end{array}$ & $\begin{array}{l}-127.28 \\
-127.42 \\
-127.68\end{array}$ & $\begin{array}{c}-127.46 \\
\pm 0.18 \\
\pm 0.14 \%\end{array}$ \\
\hline \multicolumn{9}{|c|}{$50 \mathrm{mg}$ samples } \\
\hline $\begin{array}{l}735^{*} \\
738^{*} \\
741\end{array}$ & $\begin{array}{l}0.05679 \\
0.04907 \\
0.05163\end{array}$ & $\begin{array}{l}0.017920 \\
0.015480 \\
0.016269\end{array}$ & $\begin{array}{l}49.992 \\
49.997 \\
49.983\end{array}$ & $\begin{array}{l}3871.5 \\
3870.8 \\
3874.0\end{array}$ & $\begin{array}{l}3871.6 \\
3871.1 \\
3873.8\end{array}$ & $\begin{array}{l}-127.52 \\
-127.46 \\
-127.42\end{array}$ & $\begin{array}{l}-127.52 \\
-127.47 \\
-127.42\end{array}$ & $\begin{array}{c}-127.47 \\
\pm 0.04 \\
\pm 0.03 \%\end{array}$ \\
\hline \multicolumn{9}{|c|}{25 mg samples } \\
\hline $\begin{array}{l}736 \\
740^{*} \\
743 \\
751 \\
752^{*}\end{array}$ & $\begin{array}{l}0.02529 \\
0.02509 \\
0.02553 \\
0.02587 \\
0.02500\end{array}$ & $\begin{array}{l}0.007897 \\
0.007794 \\
0.008059 \\
0.008027 \\
0.007925\end{array}$ & $\begin{array}{l}50.000 \\
49.995 \\
49.981 \\
49.975 \\
49.975\end{array}$ & $\begin{array}{l}3875.8 \\
3870.4 \\
3872.5 \\
3873.1 \\
3869.5\end{array}$ & $\begin{array}{l}3876.1 \\
3871.7 \\
3873.1 \\
3873.0 \\
3869.5\end{array}$ & $\begin{array}{l}-126.33 \\
-125.50 \\
-127.60 \\
-125.45 \\
-128.04\end{array}$ & $\begin{array}{l}-126.34 \\
-125.55 \\
-127.62 \\
-125.44 \\
-128.04\end{array}$ & $\begin{array}{c}-126.59 \\
\pm 1.12 \\
\pm 0.89 \%\end{array}$ \\
\hline \multicolumn{9}{|c|}{$10 \mathrm{mg}$ samples } \\
\hline $\begin{array}{l}771 \\
774^{\star} \\
775 \\
776^{\star}\end{array}$ & $\begin{array}{l}0.01052 \\
0.00970 \\
0.01070 \\
0.00977\end{array}$ & $\begin{array}{l}0.003210 \\
0.003043 \\
0.003359 \\
0.003072\end{array}$ & $\begin{array}{l}49.944 \\
49.995 \\
49.956 \\
49.968\end{array}$ & $\begin{array}{l}3872.0 \\
3868.8 \\
3872.9 \\
3869.2\end{array}$ & $\begin{array}{l}3871.3 \\
3867.9 \\
3872.7 \\
3868.7\end{array}$ & $\begin{array}{l}-123.31 \\
-126.70 \\
-126.92 \\
-126.99\end{array}$ & $\begin{array}{l}-123.29 \\
-126.67 \\
-126.91 \\
-126.97\end{array}$ & $\begin{array}{c}-125.97 \\
\pm 1.65 \\
\pm 1.31 \%\end{array}$ \\
\hline
\end{tabular}

Notes: Calorimetric heat capacity I is measured before dissolution, heat capacity II after dissolution. Raw values for all enthalpies of solution have been multiplied by 0.998 for reasons noted by Hovis and Roux (1993, p. 1116). In the last column " \pm 1 standard deviation (\%)" gives 1 standard deviation expressed as a percentage of the average heat of solution.

* Dissolved in acid of the preceding experiment.

ergy that one is attempting to detect, as a general rule compounds generating heats of solution of $-2000 \mathrm{~J} / \mathrm{g}$ produce highest-quality results for sample sizes down to $25 \mathrm{mg}$ per dissolution. For projects requiring less precision, around $1-2 \%$, the minimum required sample will be even lower, perhaps $5 \mathrm{mg}$. This reduction in required sample size makes possible many new projects, including those on high-pressure materials, which have not previously been approachable by $\mathrm{HF}$ solution calorimetric investigation.

\section{ACKNOWLedgments}

We are grateful for the support of this work by the Earth Sciences Division of the National Science Foundation through grant EAR-9613710. We thank William Carey, Alexandra Navrotsky, and especially Bruce Hemingway for their thoughtful reviews of this manuscript. Hilary Alberti helped produce Figure 1, and Joyce Hovis assisted with proofreading.

\section{REFERENCES CITED}

Hemingway, B.S. and Robie, R.A. (1977) Enthalpies of formation of low albite $\left(\mathrm{NaAlSi}_{3} \mathrm{O}_{8}\right)$, gibbsite $\left(\mathrm{Al}(\mathrm{OH})_{3}\right)$, and $\mathrm{NaAlO}_{2}$; revised values for $\Delta H_{\mathrm{f} .298}^{0}$ and $\Delta G_{\mathrm{f}, 298}^{0}$ of some aluminosilicate minerals. Journal of Research of the United States Geological Survey, 5, 413-429.
Hovis, G.L. (1974) A solution calorimetric and X-ray investigation of AlSi distribution in monoclinic potassium feldspars. In W.S. MacKenzie and J. Zussman, Eds., The feldspars, p. 114-144. Manchester University Press, Manchester, U.K.

(1988) Enthalpies and volumes related to K-Na mixing and Al-Si order/disorder in alkali feldspars. Journal of Petrology, 29, 731-763.

(1997) Hydrofluoric acid solution calorimetric investigation of the effect of anorthite component on enthalpies of K-Na mixing in feldspars. American Mineralogist, 82, 149-157.

Hovis, G.L. and Roux, J. (1993) Thermodynamic mixing properties of nepheline-kalsilite crystalline solutions. American Journal of Science, 293, 1108-1127.

Robie, R.A. and Hemingway, B.S. (1972) Calorimeters for heat of solution and low-temperature heat capacity measurements. United States Geological Survey Professional Paper 755.

Roux, J. and Hovis, G.L. (1996) Thermodynamic mixing models for muscovite-paragonite solutions based on solution calorimetric and phase equilibrium data. Journal of Petrology, 37, 1241-1254.

Waldbaum, D.R. and Robie, R.A. (1971) Calorimetric investigation of Na$\mathrm{K}$ mixing and polymorphism in the alkali feldspars. Zeitschrift fur Kristallographie, 134, 381-420.

Manuscript Received February 10, 1998

Manuscript aCCEPTED April 3, 1998

Paper handled by J. William Carey 